\title{
PARTICIPATORY BUDGETING PRACTICES AND CIVIC ACTIVISM FOR URBAN SPACE RENOVATION: THE CASE OF KHERSON
}

\section{Daria MALCHYKOVA}

Kherson State University, Ukraine darina13@i.ua

\begin{abstract}
The article presents the results of the participatory budgeting research and urban activism in the renovation of the urban space of Kherson, and analyzes the modern features of urban space transformation. Participatory planning and budgeting today are the guidelines for the development of new, joint and integrated decisions in strategic development of the community. However, the Kherson city case study proved urban activism on issues of participatory budgeting to be small-scale in nature, which means that $2-5 \%$ of the city community is involved in budgeting, and the total cost of approved projects is less than $0.5 \%$ of the average annual city's budget. Urban activism is quite sporadic beyond the participatory budgeting, which is the result of "small initiatives" of individual creative groups and entrepreneurs, rather than a strategic plan for spatial development of the community. The participatory budgeting in the Kherson city community development is still pseudo-participatory in its nature, given that much of decisions are aimed at solving the current domestic and communal problems, rather than implementing the agenda or strategic goals of community development.

In the era of actual city deindustrialization, Kherson should not only be positioned as one of the leaders in foreign and domestic tourism, but also restore its status of a comfortable city and a unique recreational and logistics center. The article presents the author's vision of the planning decisions and urban activism prospects in the urban spaces' transformation. The key points are the next: 1) renovation and revitalization of urban space should be carried out primarily by creating different types and functional purposes of creative spaces (new formats of recreation, communication, information education, inclusive environment development); 2) creation or renovation of existing public spaces should be carried out only with the involvement of participatory management mechanisms in order to provide the city with the functional content really needed by the community; 3 ) a particular strategic direction of urban space renovation should aim at the increase of green public spaces and benefiting from the unique Kherson city community location at the mouth of the Dnieper.
\end{abstract}

Key words: urban space, public space, citizen activism, participatory budgeting, renovation, Kherson.

DOI: https://doi.org/10.17721/2413-7154/2021.85.38-48

UDC: 911.3:711.168:316.43(477.72-21Kherson)

Received: January 18, 2021.

Accepted: February 25, 2021.

\section{ПРАКТИКИ ПАРТИСИПАТИВНОГО БЮДЖЕТУВАННЯ I МІСЬКИЙ АКТИВІЗМ У РЕНОВАЦІЇ МІСЬКОГО ПРОСТОРУ: КЕЙС М.ХЕРСОН}

\author{
Дар'я МАЛЬЧИКОВА \\ Херсонський державний університет, Україна \\ darina13@i.ua
}

Анотація: У статті представлено результати дослідження практики партисипативного бюджетування і міського активізму у реновації міського простору м. Херсон, проаналізовано сучасні риси трансформації міських просторів. Партисипативне планування і бюджетування $\epsilon$ сьогодні основою вироблення нових спільних, інтегрованих рішень щодо стратегічного розвитку громади. Разом з тим, під час дослідження кейсу м. Херсон визначено, що міський активізм у питаннях партисипативного бюджетування має дрібномасштабний характер - залучено до бюджету участі 2-5\% населення міської громади, а загальна вартість схвалених проєктів складає менше 0,5\% від середньорічного обсягу бюджету міста. Міський активізм поза партисипативним бюджетуванням має епізодичні прояви, зумовлені «малими ініціативами» окремих творчих колективів, підприємців, а не стратегічним планом просторового розвитку громади. Бюджет участі у розвитку херсонської міської громади поки що має в цілому характер псевдоучасті, оскільки переважна більшість прийнятих рішень фактично спрямовані на вирішення поточних проблемних ситуацій побутового і комунального характеру, а не реалізують порядок денний чи стратегічні цілі розвитку громади.

В епоху фактичної деіндустріалізації міста Херсон має позиціонуватися не тільки як один із лідерів різнопланового зовнішнього та внутрішнього туризму, але і відновити свій статус комфортного міста, унікального рекреаційного і логістичного центру. У статті представлено авторське бачення перспективи планувальних рішень і міського активізму у трансформації міських просторів. До ключових моментів віднесено: 1) реновація та ревіталізація міського простору має здійснюватися перш за все шляхом створення креативних просторів різних типів і функціонального призначення (нові формати відпочинку, спілкування, інформальної освіти, розбудови інклюзивного середовища); 2) створення або оновлення існуючих публічних просторів має здійснюватись лише із залученням механізмів партисипативного управління, щоб забезпечити місто реально необхідним громаді функціональним наповненням; 3) окремим стратегічним напрямом реновації міського простору має стати збільшення частки зелених публічних просторів і використання переваг унікального розташування херсонської міської громади у гирлі р. Дніпро.

Ключові слова: міський простір, публічний простір, міський активізм, партисипативне бюджетування, реновація, Херсон. 


\section{Introduction}

Since 2008, with the beginning of the new "urban millennium" and for the following 30 years, it is expected that two thirds of the world's population will live in urban areas (Transforming our world... 2015). The importance of urban issues for global efforts on the implementation of the Sustainable Development Model is emphasized in the 2030 Agenda by highlighting the Sustainable Development Goals 11 "Ensuring openness, security, resilience and environmental sustainability of cities and localities". Let's consider that in the long run the well-being of cities and their inhabitants is determined primarily by the efficiency of organization and planning of urban spaces, infrastructure development and quality of utilities, risk minimization and meeting the needs of the population. All this is possible only on condition that there is a connection between the spatial form of the city and the social process and is realized through the relationship between the design of urban spaces and a certain ideology of the urban community.

The transformation of urban space has been an ongoing process in many cities over decades and centuries. At the same time, this process is undergoing significant changes in terms of driving forces that cause the corresponding transformations. The practice of initiating changes involving the public society (Falanga, 2020) is becoming more widespread in the world community, and it is increasingly introduced in Ukraine (Buletsa, 2016; Dorosh, 2019).

Urban activism stimulation and participation budgeting are the most prospective today (Baiocchi, 2001; Krenjova \& Raudla, 2013; Hope for democracy... 2018; etc.), as the transformation due to "small initiatives" with public participation, enables residents not only to participate in making budget decisions, but also to join the transformation of urban space. Historical evolutionary changes in urban spaces in some periods are accompanied by global challenges that add uncertainty in finding the most optimal strategies for urban development. In particular, it is expected (Sharifi, 2020) that the COVID-19 pandemic will further radically change urban governance and urban planning.

The de-industrialization stage, experienced by the city of Kherson in the post-Soviet period, and the specific features of the geographical location that determine the trends of spatial development of the city (Malchykova \& Pylypenko, 2017) determine the search for new concepts of urban development. The Kherson urban spaces are undergoing significant transformations, and the introduction of participatory management models has led to the emergence of certain research questions:

- How can we assess the current state of transformation and renovation of urban spaces?

- What spatial resources are of the greatest value in the light of further transformations of urban spaces, and therefore they should become objects of urban activism in the future?

- How effective is the introduction of the participation budget and what is the contribution of urban activism to the formation of a quality socio-spatial structure of Kherson today?

- What are the prospects for the planning decisions and urban activism prospects in the urban spaces' transformation?

Taking into the consideration all the above-mentioned, the aim of this paper is the analysis of participatory budgeting and urban activism in the renovation of the urban space of Kherson and further identification of high-potential areas of urban planning and components of urban activism in the transformation of urban spaces.

Analysis of recent publications and research. Urban issues in Ukraine are represented in numerous periodicals and monographs in all matters: scientists and practitioners note on modern changes of urban spaces (Changes in the urban space in Ukraine ... 2013; Nemets et al., 2017; Suptelo, 2020), emphasize the variety of ways to transform post-Soviet of cities (City and Renewal... 2013; Afanasieva \& Kuznetsova, 2017), highlight current regional patterns and ways of future development of Ukrainian cities (Bykova, 2014; Urban Ukraine... 2017; Mezentsev et al., 2019), etc.

The search for an alternative paradigm of urban development dates back to the 1970s. (Harvey, 1994), when the crisis in urban living conditions due to the accelerated industrial development of cities led to the search for new concepts of planning. Urban renaissance became a key policy issue in the 1980s (Shaw, 2020), and since then it has been dominating in urban planning programs along with new euphemisms - renovation, revitalization, regeneration, etc. In response to the concept of "new urbanism" (Dronova, 2015; Mezentseva, 2017) sustainable, transit, creative, intelligent and mixed use of urban spaces characterize modern planning approaches today, and the variety of new urbanism forms are summarized in three types: basic, dense and hybrid, based on geographical and temporal aspects of the designed environments (Trudeau, 2013).

The new theory of urbanism includes new ways of thinking about the city form and its development (Bohl, 2002; Ghorbi \& Mohammadi, 2019), which is based primarily on finding an answer to the question "How can modernization of the city help create a prosperous, content community?" In this context, the formal discourse on the role of communities in urban rebirth and regeneration has been going on for more than a few decades (Atkinson, 1999; Jones, 2003). Participatory budgeting is one of the ways for communities to participate in urban transformation. Participatory budgeting is considered to be the best-known democratic innovation in the field of research and practice, and global practices of the last decade are no longer aimed at introducing participatory budgeting, but at finding ways to include previously excluded social groups in the participatory process (Hernández-Medina, 2010).

Participation as a model for developing new common, integrated solutions has been used for several decades in various spheres of social life and is analyzed by researchers as a basis for developing sustainable development strategies (Bass et al., 1995), local 
government practice (Olchak, 2017), civic development and adaptation to climate change in cities (Sarzynski, 2015) and even art projects (Bowell, 2014).

Participatory urban planning is regarded as a planning paradigm that involves the community of the city, its residents, into the processes of urban planning (Mezentsev et al., 2020), local communities are seen as partners in urban design processes, and in many countries their role in planning and design is determined by trade standards. However, the search for an answer to an important question: "Is public participation a formal tool, does it influence planning and how does it influence decision-making?” (Korolıova \& Treija, 2019), provides an opportunity to talk about possible formalizations and the lack of real public influence on the processes of urban transformation. Modern researchers (Palacin et al., 2020) characterize such a phenomenon as pseudo-participation, determining the lack of real power in decision-making and determining the agenda of community development.

In addition to that, a revision of the concept of modern urban space (Carmona, 2015) and a study of the transformation of public spaces in the cities of developing economies (Mandeli, 2019), showed that there are other threats. Public expectations of modernization, strong civic activism, and new governance practices rapidly and radically changed urban spaces, but a radically redeveloped city appeared to be filled with absolutely unsuitable public spaces that did not meet people's daily needs and aspirations. Therefore, it is justified that local authorities should on one hand encourage public participation and allow various stakeholders to participate in discussions on planning, creation and use of public spaces, but on the other hand they are bound to ensure the work of an independent technical commission, which will analyze urban projects in accordance with guidelines for creation of better places (Mandeli, 2019).

Presentation of the main research material. Kherson city is the administrative, industrial, cultural center of the Kherson region, and at the same time it is the center of the Kherson city territorial community, which today concentrates $1 / 3$ of the population of the region: according to the Main Department of Statistics in the Kherson region (http://www.ks.ukrstat.gov. $\mathrm{ua} /$ ) the population in the Kherson City Council as of October 1, 2020 amounted to 322.19 thousand people. But apart from the actual human resources, in modern society the uniqueness of the location of territory, history, culture and the ability to transform become the decisive factors in the attraction of people, investment, modern activities. The uniqueness of Kherson is the combination of the most valuable natural landscapes of the mouth of the Dnipro river, and historical and cultural heritage, the uniqueness of the transport and logistics situation. A special feature of Kherson is its location on the right bank at the mouth of the Dnipro river, the city actually "controls" the point of braiding of river channels, the upper part of the delta, the spot of formation of its lower arms. Due to its geographical location, Kherson has a developed network of transport infrastructure, it is the only seaport on the Dnipro, a river port, a railway junction, and an airport.
The location at the mouth of the Dnipro with its long coastal areas is an incredible resource for the development of Kherson, which can be the basis for the transformation of public recreational spaces in both urban and suburban areas. This thesis is also confirmed by the results of an interactive survey on the strategic vision of the city (Fig. 1), published on the official website of the Kherson City Council (http://www.city.kherson.ua/).

Thus, in the competitive environment of urban centers of Ukraine and Europe today, Kherson should be positioned not only as one of the leaders in foreign and domestic tourism, but also to restore its status as a comfortable city, a unique recreational and logistics center. The mission of the city is to preserve, multiply and effectively use its spatial uniqueness in the interests of present and future generations throughout Ukraine.

It is quite common to use coastal/riparian settlements, territories located directly in the coastal zone in the public everyday practices of the city, as they are the most attractive and valuable. However, urban spaces, which should be the basis in creation of an attractive river image of Kherson, do not perform such functions today. The length of the 2 public embankments (in the area of the Frigate Hotel and the Slavy Park) is only about 500 meters. Moreover, they are separated by territorial cargo terminals of the Kherson Sea Commercial Port. All other coastal areas are territories of either private construction or production zones of the city's enterprises, such as Kherson Shipyard, Palada Plant, Kherson Ship Building and Ship Repair Plant. And the territory of the river station "Richmorvokzal", which is located in the city center and is unique for Ukraine, stays abandoned and underused today, due to the unprofitability of river passenger transportations by the boats of "Ukrrichflot" and the lack of other functional purpose (Fig. 2).

The urban space of Kherson during the XX century was significantly "Sovietized" and industrialized, which today is associated with certain spatial practices, especially with the location of industrial enterprises within the central part of the city. However, the deindustrialization of the city, which actually took place during the years of independence, led to shutdown or significant reduction of industrial production, and as a result of this, numerous areas of production facilities were abandoned and dilapidated (examples Fig. 3). It is important that most of these enterprises (engineering, light industry) are located within the most valuable areas of the central part of the city or in close proximity to it (Kherson Machine-Building Plant named after G. I. Petrovsky, Electromash Concern, Kherson Cardan Shaft Plant, Kherson Shoe Factory, Kherson Bolshevik Garment Factory), or are in favorable transport and logistics conditions (Kherson Cotton Plant) and are a valuable spatial resource for revitalization and renovation projects.

There is no doubt that there are some successful revitalization and renovation projects within the urban spaces of Kherson: shopping mall Fabryka in the premises of the Kherson Cotton Plant; residential building, creative space Urban CAD and medical 


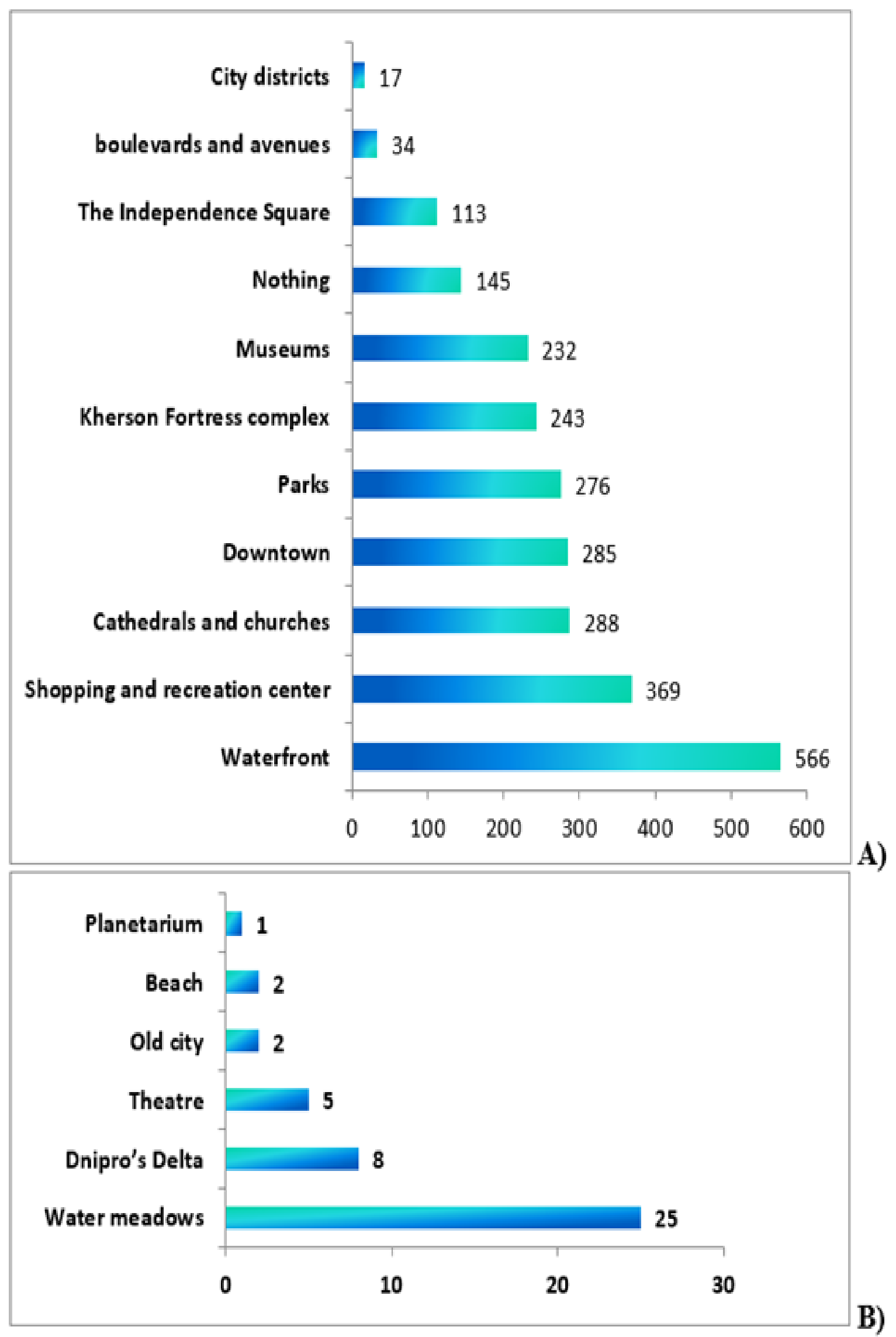

Fig. 1. The results of the survey on the question "What would you definitely show to your guests in Kherson?" A) options, proposed during the survey; B) options, added by respondents (Based on: http://www.city.kherson.ua/articles/strategiya-rozvitku-m-hersona-do-2030-roku?printable=1) 

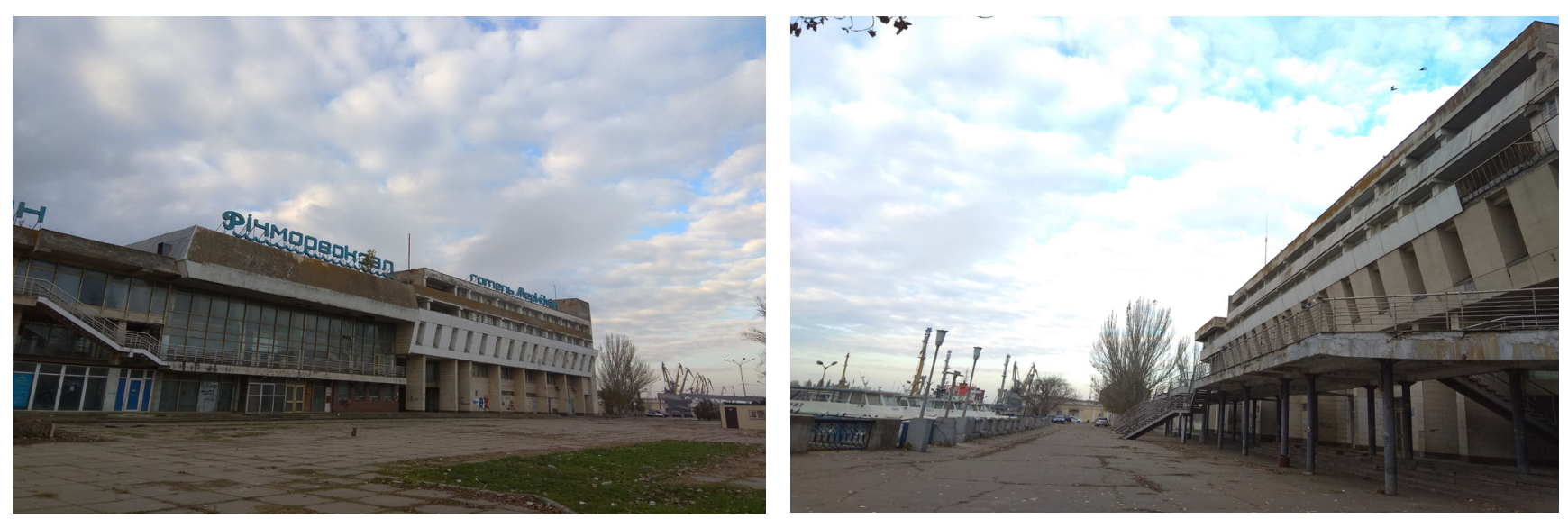

Fig. 2. The current state of the premises of "Richmorvokzal" and adjacent public spaces (Photo: D. Malchykova, 2020)

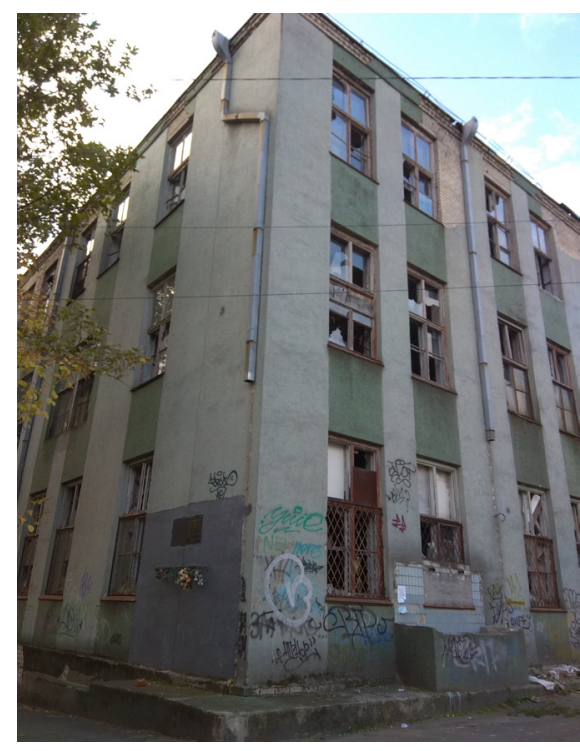

A) Premises of a former shoe factory

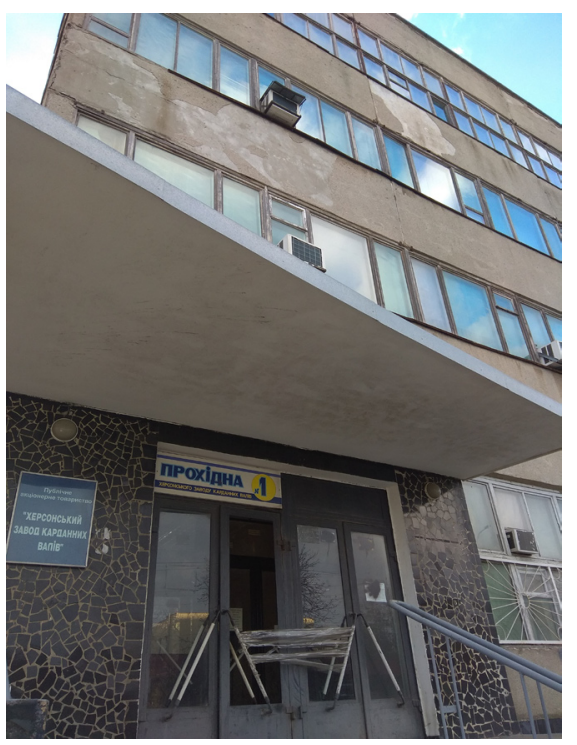

B) Premises of "Kherson Cardan Shaft Plant"

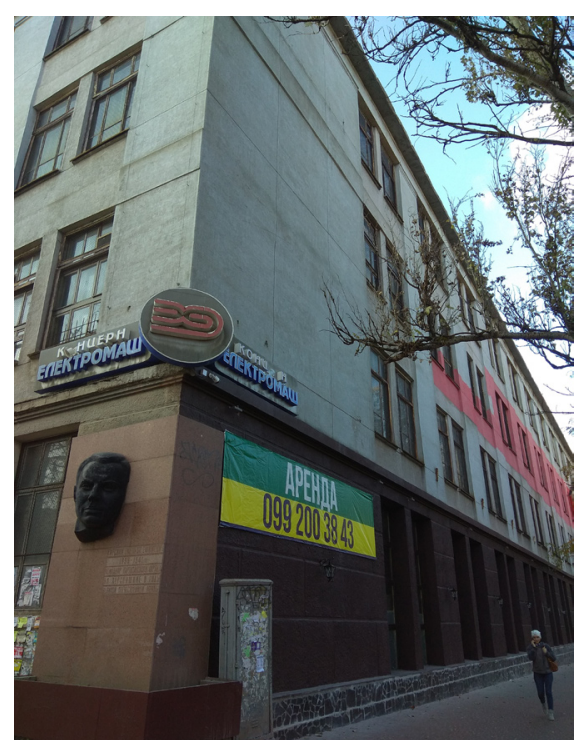

C) Premises of the concern "Electromash"

Fig. 3. Premises of industrial enterprises in the central part of Kherson and the experience of their partial revitalization (C) (Photo: D. Malchykova, 2020)
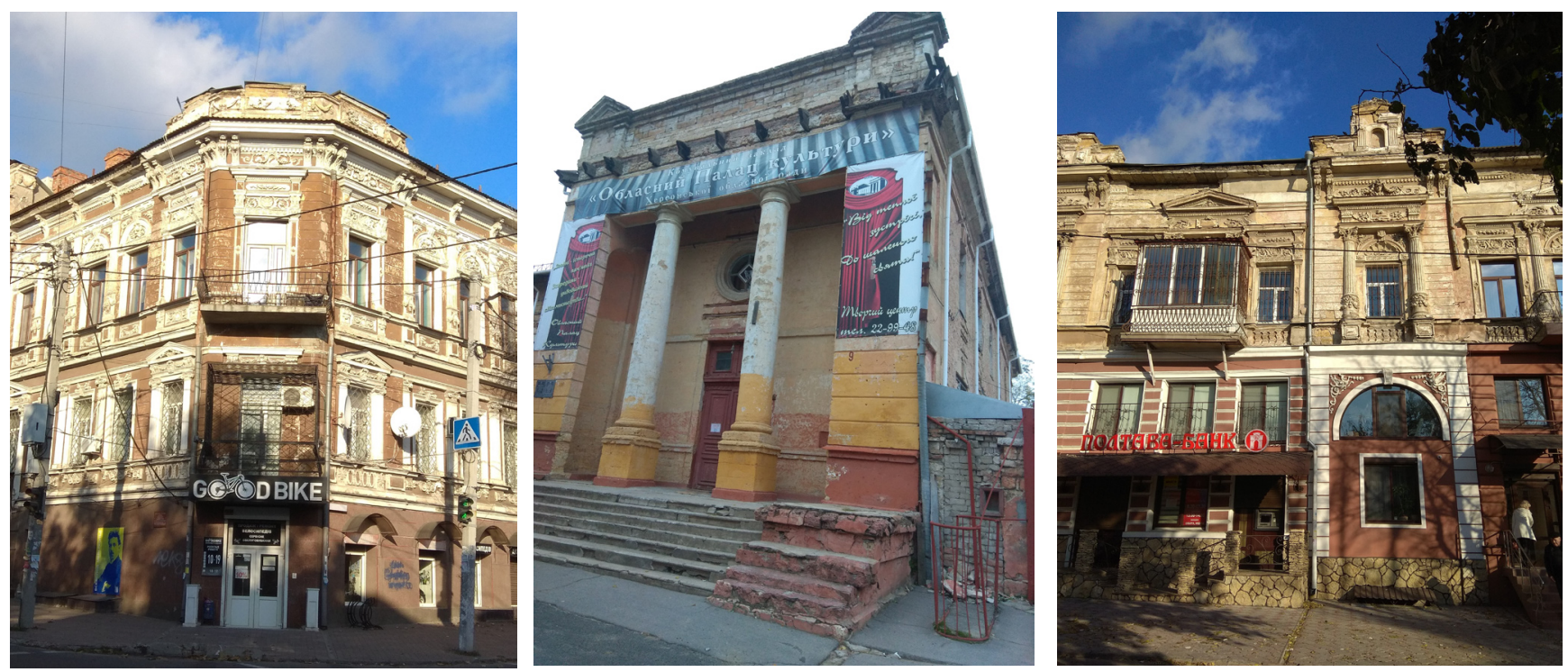

Fig. 4. The practice of renovating buildings in the center of the city. Kherson (Photo: D. Malchykova, 2020) 
diagnostic center "Taurt-Medical" on the territory of separate premises of the Kherson Machine-Building Plant named after G. I. Petrovsky; Partial renovation of buildings of Concern "Elektromash" for offices, shopping and entertainment facilities (Fig. 3B); separation of a part of a garment factory for housing stock and renewal of production capacities in another part, etc. Such examples of urban activism are episodic, and they are made not due to a strategic plan and decisions on spatial development of the community, but "small initiatives" of individual creative teams or entrepreneurs.

Abandoned areas of industrial enterprises, which have fully or partially suspended their activities, significantly reduce the attractiveness of the city, destroy the sense of local identity, create unusable urban spaces, leaving a huge potential for large-scale commercial and residential construction untapped.

It should be noted that the city has examples of complex restoration and renovation of architectural monuments, administrative buildings of institutions or organizations mainly (Fig. 4).
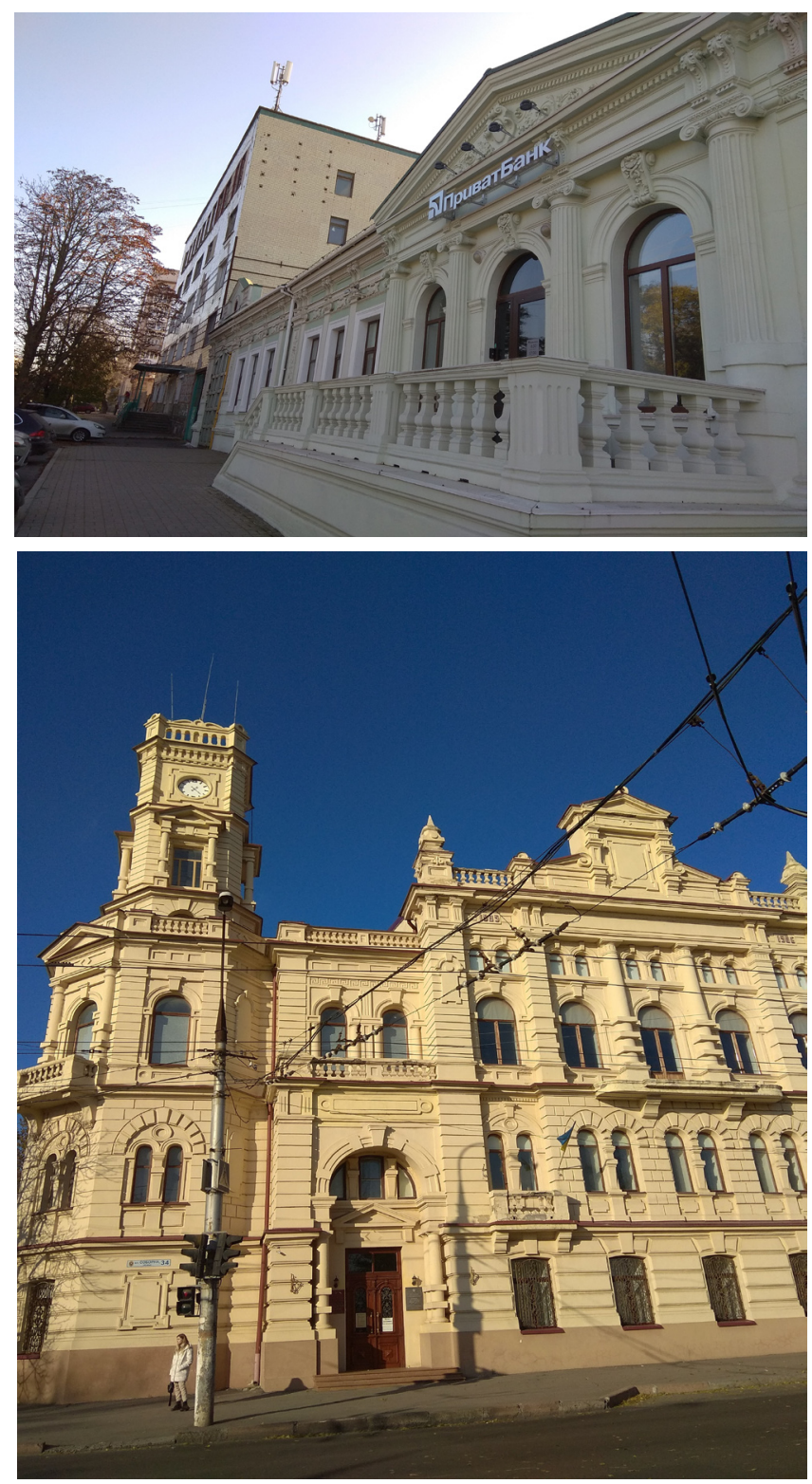

On the other hand, the housing stock, cultural, social institutions are either not renovated, or are partially restored, and very often requirements for the preservation of the architectural ensemble are not followed (Fig. 5). The political and economic transition from central government in the communist one-party system to the political democracy and market economy of the post-communist countries of Central and Eastern Europe inevitably led to a reassessment of the functions, role, aesthetics of space and significant urban transformation in all post-Soviet states. The study (Hamilton 1995) identified three types of spatial differentiation: 1) first, differences in the speed and scale of reforms that cause national, regional and local spatial differences; 2) second, regions that were previously "over-industrialized" and today suffer from severe deindustrialization will undergo powerful processes of demolition, restructuring or liquidation of spatial inner-city structures; 3 ) crossborder with the European Union or metropolitan regions will experience "reindustrialization" and adapt more quickly to a clear reorientation in trade relations and economic and social integration of territories.
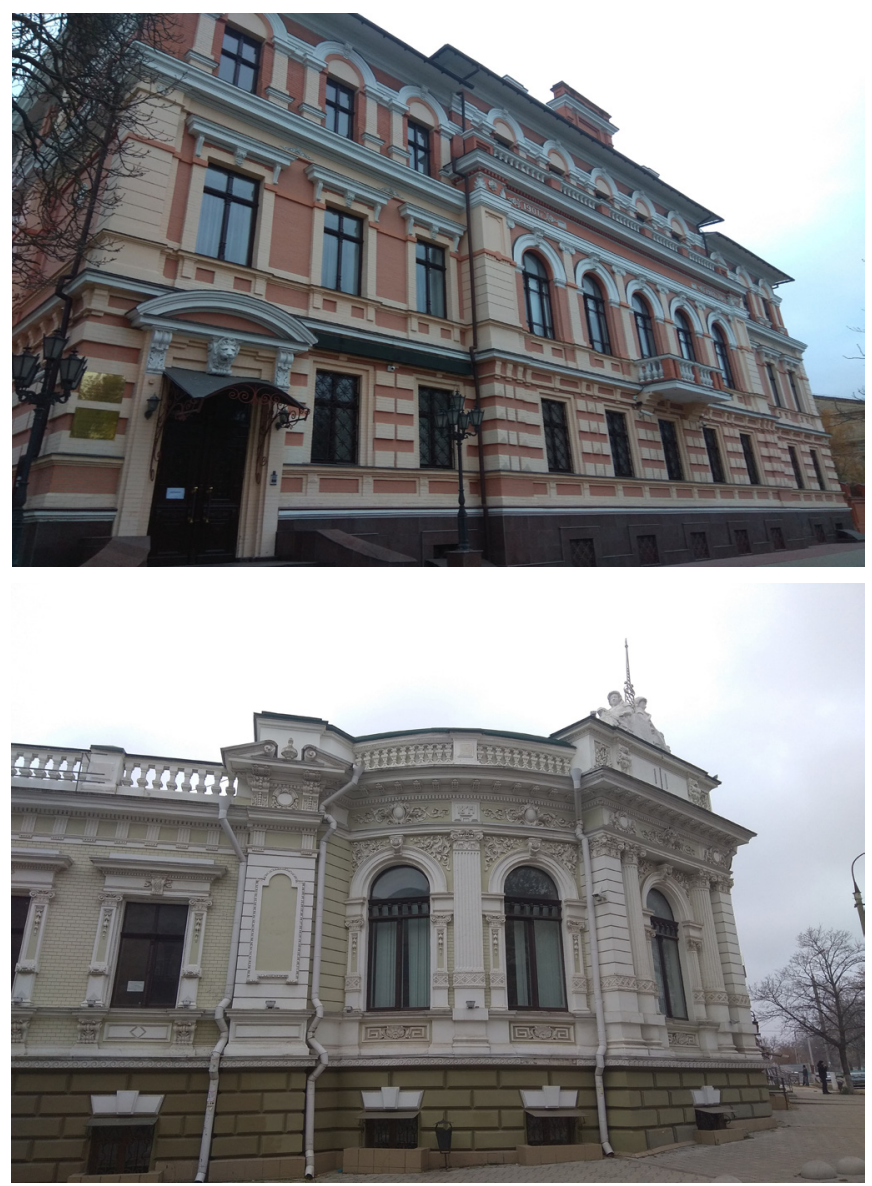

Fig. 5. Examples of complex renovation of buildings which are architectural monuments in the downtown area of Kherson (Photo: D. Malchykova, 2020) 
Characteristic features in the location and history of industrial development identified Kherson as the 2 type (severe deindustrialization), which later added up to the specifics of local government and low public consciousness of the urban community. The contrariety and slowness of the transformation of the urban spaces of Kherson led to the violations of the functionalism and aesthetic problems of the city. Therefore, the Development Strategy of Kherson by 2030 on a new conceptual basis has become the leading task of local self-government at the moment.

In September-October 2020, the city hosted an interactive survey of representatives of business and scientific areas, local government and the public of Kherson on the strategic vision of the future of the city in the context of the Development Strategy of Kherson by 2030. The published results of the survey (http://www. city.kherson.ua/articles/strategiya-rozvitku-m-hersonado-2030-roku?printable=1) unfortunately confirmed the negative public perception of the current realities of the city development and stated the urgent need for new urban development strategy. In particular, it is extremely sad that almost $30 \%$ do not see prospects for development in the urban community, only $2.5 \%$ of respondents would recommend their friends the Kherson community to live in, while $11 \%$ of respondents said that they would leave this place at the slightest opportunity. It is significant that the Kherson community today is not satisfied with any development and daily life index (Fig. 6).
Opportunities for a dialogue between the city authorities and the city community, in addition to election mechanisms, are also provided today through city political projects and institutions of advisory democracy (Dorosh, 2019). Participatory management in common sense is based on the recognition of the mutual interests of all members of the community and is implemented through the integration of these interests and increase of interest in the results of cooperation. Participatory management can have various forms (Semyanovsky, 2018): participation in revenues (budgets) and losses; participation in profits and property; participation in management. As a result of research, such tool for involving citizens as participatory budgeting was identified as one of the most successful projects (Baiocchi, 2001; Krenjova \& Raudla, 2013; Sarzynski, 2015; Hope for democracy... 2018; Mezentsev et al., 2020; Falanga, 2020).

The program of city initiatives "Platform for the implementation of ideas to improve your city" operates in Kherson during 2019-2020 and allows Kherson citizens to participate in the distribution of budget funds to improve the life of the city. A detailed analysis of participation budget statistics showed that urban activism on participatory budgeting in the Kherson community is small-scale. According to the public budget website (http://www.city.kherson.ua/c/hersoncyu/s/ gromadskiy-byudzhet) in 2019, 18 out of 77 submitted projects won. 11 of those projects as of November 2020

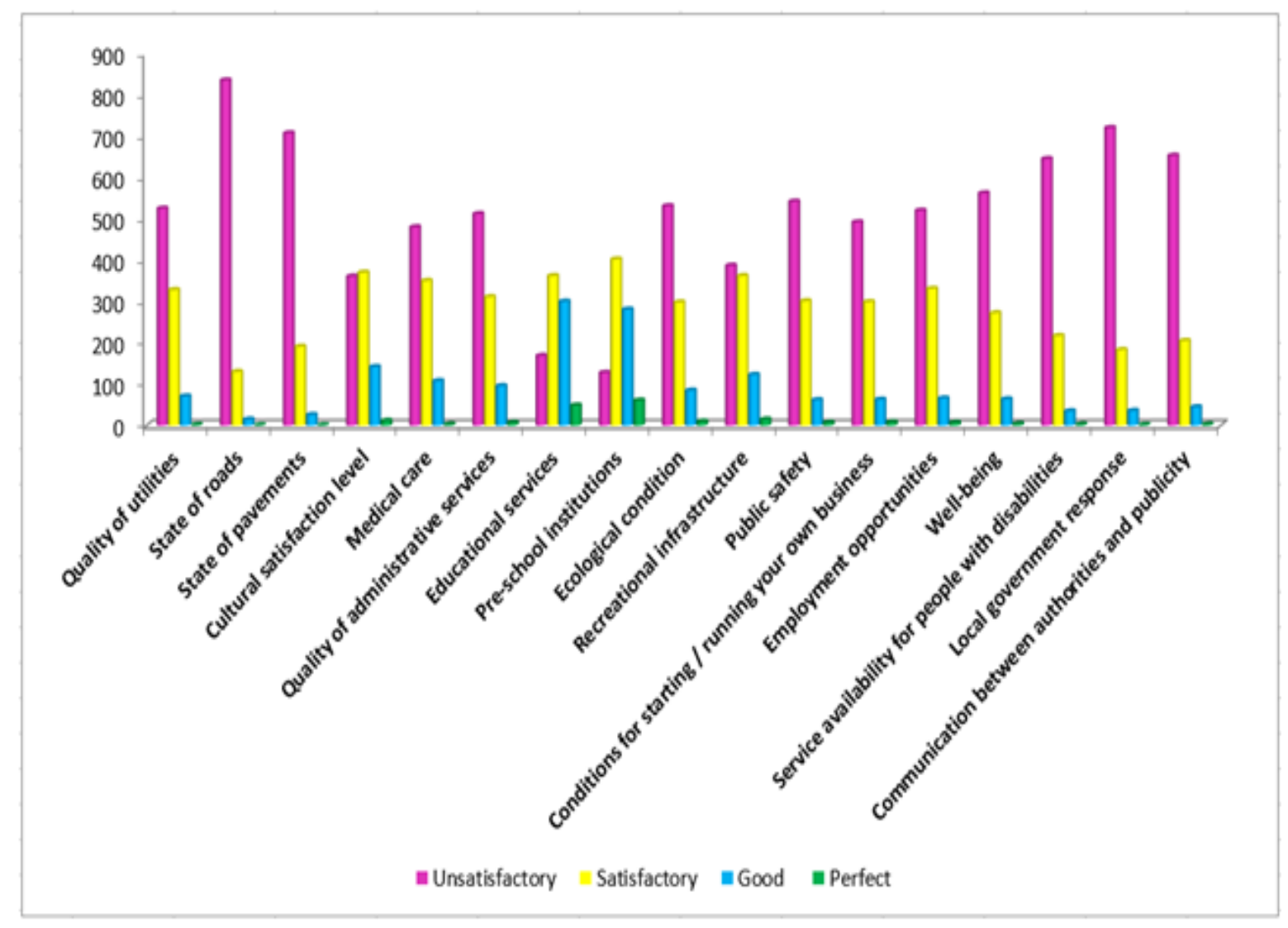

Fig. 6. The results of the survey on the question "How would you assess the current state of certain indicators of community development?"

(Based on: http://www.city.kherson.ua/articles/strategiya-rozvitku-m-hersona-do-2030-roku?printable=1) 
2019

\section{SUBMITTED PROJECTS IN CATEGORIES}

\begin{tabular}{|l|l|l|}
\hline IN TOTAL. & SMALL & BIG \\
\hline
\end{tabular}

IN TOTAL

\begin{tabular}{|c|c|c|c|}
\hline $\mathscr{P}$ Road facilities & $5(6 \%)$ & & \\
\hline 8 Energy saving & $0(0 \%)$ & & \\
\hline Q Utilities system & & $16(21 \%)$ & \\
\hline A Culture & $6(8 \%)$ & & \\
\hline (i) Environment & $0(0 \%)$ & & \\
\hline 8 Bducation & & & $29(38 \%)$ \\
\hline (6) Sport & & $17(22 \%)$ & \\
\hline P Telecommunications, communications and information & $1(1 \%)$ & & \\
\hline \$ Other & $3(48)$ & & \\
\hline
\end{tabular}

2020

SUBMITTED PROJECTS IN CATEGORIES

\begin{tabular}{|l|l|l|}
\hline IN TOTAL & SMALL & BIG \\
\hline
\end{tabular}

IN TOTAL.

\begin{tabular}{|c|c|}
\hline do Bicycle infrastructure & $0(0 \%)$ \\
\hline 0 Security and public order & $3(3 \%)$ \\
\hline B) Road facilities & $4(4 \%)$ \\
\hline
\end{tabular}

M.edla $0(0 \%)$

Q Ufillities system $5(5 \%)$

A. Culture 2(2x)

Q Environment $4(48)$

Q Education 20 (21\%)

8 Health care 1 (1\%)

S Social protection 0(0\%)

(2) Sport 31(32\%)

PTelecommunications, communications and information technolog:0 (0\%)

Div Transport 0(0\%)

$\begin{array}{lll}1 & \text { Other } & 19(20 \%)\end{array}$

Fig. 7. Categories and number of projects submitted through the participation budget program (Compiled on the basis of: http://www.city.kherson.ua/c/hersoncyu/s/gromadskiy-byudzhet) 
were implemented for the value of UAH 4.5 million, 7 projects for the value of UAH 5.3 million were in the process of implementation. Public activism on behalf of the territorial Community on the budget of participation in Kherson was extremely weak - a total of 8595 people voted (2.6\% of citizens). In 2020, 108 projects for the value of UAH 78.8 million were submitted, 175,527 Kherson residents (5.4\% of urban residents) took part in the voting, twice as many as in 2019, but this figure cannot be considered satisfactory either. In 2021, 17 projects for the value of UAH 9.6 million won. A slight increase in urban activism in participatory budgeting was accompanied by a significant expansion of categories variety for submitted projects (from 9 to 15) (Fig. 7), but the further project analysis revealed that the participatory budgeting in the Kherson city community development is still pseudo-participatory in its nature, given that much of decisions are aimed at solving the current domestic and communal problems, rather than implementing the agenda or strategic goals of community development.

Most of the projects are aimed at equipping playgrounds and sports grounds, improving the technical, sanitary and hygienic conditions of public utilities, and improving the condition of the road sector. Thus, the projects of 2019 and 2020, approved through the participation budget program, were more aimed at bringing certain urban spaces and facilities to safe state, although they should anyway be in a satisfactory condition due to the appropriate sectoral funding. For example, in 2019, the project "Safe future of our children", implemented in the category "Education", provided for the complete replacement of the fence around Antonovsky nurserykindergarten № 4, which is in poor condition, to create safe conditions for children, their parents and employees on the territory of the institution. The project "Modern laundry unit in the Preschool Education Institution №4" was implemented in the same category, "Education". It provided for the overhaul of the premises and engineering networks of the laundry unit and replacement of old technical equipment with modern energy-saving ones.

Examples of community initiatives, implemented through participatory budgeting, which can at least partially be considered as real measures of urban planning, are a number of projects in 2020. For example, construction of recreational areas, paving of paths and fences, installation of energy efficient street lighting in Tavriyskyi district due to the project "Small Steps to Big Changes: "Let's modernize Kherson together!"

Among the initiatives supported by the public, in 2020 there start to emerge the projects that reflect the movement of the city community towards the creation of an inclusive environment of the Kherson city territorial community:

- "Children's Sportland" - a wonderful world for children with musculoskeletal disorders (creation of a modern innovative space for sports for children with musculoskeletal disorders, considering individual needs);
- Ecological space - "Dream Life" (creation of an ecological area for recreation and development of children with musculoskeletal disorders, considering individual needs)

Despite the small scale and somewhat distorted nature of participatory budgeting in the context of strategic goals of urban community development and urban development planning, it is necessary to emphasize the importance of developing forms of urban activism and introduction of participatory budgeting as a tool of citizen involvement. However, the concept of spatial development in Kherson city, planning decisions for the arrangement of public spaces and decisions on the renovation and revitalization of urban facilities need significant revision.

\section{Conclusion}

Research of city activism and experience of participatory budgeting in Kherson during 2019-2020 allows addressing the following conclusions:

- urban activism in participatory budgeting is small-scale: $2-5 \%$ of the city community population was involved in the budget, and a total of 35 projects with a total cost of UAH 19.4 million were approved in 2 years, which is less than $0.5 \%$ of the average annual city budget.

- urban activism apart from participatory budgeting is episodic, and they are made not due to a strategic plan and decisions on spatial development of the community, but "small initiatives" of individual creative teams, entrepreneurs, etc.;

- the participatory budget in the Kherson city community development is still of pseudo-participation in the nature, as much of decisions are aimed to solve the current domestic and communal problems, rather than implement the agenda or strategic goals of community development.

The practice of participatory budgeting and urban activism in the renovation of urban space (in particular, public spaces) in Kherson has isolated examples so far. In our opinion, the prospects of planning decisions and urban activism in the transformation of urban spaces can be summarized as follows:

1) Renovation and revitalization of urban space, in particular the territories of non-functioning industrial enterprises, should be carried out not only by creating shopping and entertainment or office centers, but above all by creation of creative spaces of different types and functional purposes, which would allow new formats of recreation, communication, information education, development of inclusive environment. The revitalized territories of such enterprises should play the role of interstitial spaces in the city and form a new image of the community and the rhetoric of the local civic consciousness.

2) The creation or renovation of existing public spaces should be carried out only with the involvement of participatory management mechanisms to avoid disordered commercialization, uneven placement of shopping and entertainment centers, to provide the city with the necessary functional content of the community.

3) Public councils under local self-government bodies, which perform advisory and expert functions, 
are an important mechanism for strengthening urban activism in the spatial development and distribution of the community budget. At the same time, the mechanisms for forming their staff are often subjective and need to be updated in terms of staffing improvement of staffing table, in order to prevent monopolization of decision-making.

4) A separate strategic direction of urban space renovation should be the increase of the share of green public spaces and the use the benefits of the unique location of the Kherson city community at the mouth of the river. Dnipro river. In the era of actual city de-industrialization, Kherson should be positioned not only as one of the leaders in various foreign and domestic tourism, but also to restore its status as a comfortable city, a unique recreational and logistics center.

\section{References:}

Afanas’yeva, L., \& Kuznetsova, A. (2017). Tactical urbanism as the concept of active designing of social-spatial practices of a modern city. Scientific and theoretical almanac "Grani», 20(8), 43-49. [in Ukrainian]. [Афанасьєва Л. В., Кузнєцова А. С. Тактичний урбанізм як концепція активного проектування соціально-просторових практик сучасного міста // Науково-теоретичний альманах Грані. 2017. 20(8). С. 43-49]

Atkinson, R. (1999). Discourses of partnership and empowerment in contemporary British urban regeneration. Urban Studies, 36(1), 59-72.

Baiocchi, G. (2001). Participation, activism, and politics: the Porto Alegre experiment and deliberative democratic theory. Politics \& Society, 29(1), 43-72.

Bass, S., Dalal-Clayton, B., \& Pretty, J. (1995). Participation in strategies for sustainable development. Environmental Planning Issues, 7, 118 p.

Bohl, C. (2002). Place Making: Developing town centers, main streets, and urban villages. Washington: Urban Land Institute.

Bowell, I. (2014). Community arts projects: enhancing, teaching, and learning. The International Journal of Arts Education, 8(2), 43-54.

Buletsa, N. (2016). The features of participatory budgeting process in Ukraine. Prychornomorski ekonomichni studii, 8, 148-154. [In Ukrainian]. [Булеца Н. В. Особливості процесу партисипативного бюджетування в Україні // Причорноморські економічні студії. 2016. Вип. 8. С. 148-154.]

Bykova, M. (2014). The main directions of post-industrial transformations of the city of Kyiv: branch and spatial aspects. Scientific Bulletin of Drahomanov National Pedagogical University: Series 4 Geography and Modernity, 19(31), 157-173. [In Ukrainian]. [Бикова M. D. Основні напрямки постіндустріальних трансформацій міста Києва: галузевий та просторовий аспекти // Науковий часопис НПУ імені М. П. Драгоманова: Серія 4 «Географія і сучасність». 2014. Вип. 19 (31). С. 157-173]

Carmona, M. (2015). Re-theorising contemporary public space: a new narrative and a new normative. Journal of Urbanism: International Research on Place Making and Urban Sustainability, 8(4), 373-405.

City and Renewal. Urban Studies (2013). Eds.: S. Shlipchenko, V. Tyminskyi, A. Makarenko, L. Males, I. Tyschenko. Kyiv: FOP Moskalenko O. M. [In Ukrainian]. [Місто й оновлення. Урбаністичні студії / [Редкол.: С. Шліпченко, В. Тимінський, А. Макаренко, Л. Малес, І. Тищенко]. Київ: ФОП Москаленко О. М., 2013.360 с.]

Dorosh, B. (2019). The Models of Application of the Participation Budget: the European Experience and Prospects of Application in Ukraine. Biznes Inform, 2, 58-63. [In Ukrainian]. [Дорош Б. Й. Моделі застосування бюджету участі: європейський досвід і перспективи застосування в Україні // Бізнес Інформ. 2019. № 2. С. 58-63.]

Dronova, O. (2015). New urbanism: in search for a way out of urban collapse. Ukrainian Geographical Journal, 3 , 33-41 [In Ukrainian]. [Дронова О. Новий урбанізм: у пошуках виходу з урбаністичного колапсу // Український географічний журнал. 2015. Вип. 3. С. 33-41.]

Falanga, R. (2020). Formulating the success of citizen participation in urban regeneration: Insights and perplexities from Lisbon. Urban Research \& Practice, 13(5), 477-499.

Ghorbi, M., \& Mohammadi, H. (2019). A critical view on new urbanism theory in urban planning: from theory to practice. Space Ontology International Journal. Architecture, Urban Design, and Planning, 6, 89-97.

Hamilton, F. E. I. (1995). Re-evaluating space: locational change and adjustment in Central and Eastern Europe. Geographische Zeitschrift, 83(2), 67-86.

Harvey, D. (1997). The new urbanism and the communitarian trap, Harvard Design Magazine, 1, 1-3, [Online]. Available at: http://www.harvarddesignmagazine.org/issues/1/the-new-urbanism-and-the-communitarian-trap.

Hernández-Medina, E. (2010). Social inclusion through participation: the case of the participatory budget in São Paulo. International Journal of Urban and Regional Research, 34, 512-532.

Hope for democracy. 30 years of participatory budgeting worldwide (2018). Ed.: N. Dias. Epic Books et Oficina.

Jones, P. S. (2003). Urban regeneration's poisoned chalice: Is there an impasse in (community) participation-based policy? Urban Studies, 40(3), 581-601.

Korolova, A., \& Treija, S. (2019). Participatory budgeting in urban regeneration: defining the gap between formal and informal citizen activism. Architecture and Urban Planning, 15(1), 131-137.

Krenjova, J. \& Raudla, R. (2013). Participatory budgeting at the local level: challenges and opportunities for new democracies. Halduskultuur - Administrative Culture, 14(1), 18-46. 
Malchykova, D. \& Pylypenko, I. (2017). From "torn" space to metropolization and suburbanization: Kherson urban agglomeration in new dimensions of urbogenesis. In Urban Ukraine: in the Epicenter of Spatial Changes. Eds.: K. Mezentsev, Ya. Oliynyk, and N. Mezentseva. Kyiv: Fenix, 326-338. [In Ukrainian]. [Мальчикова Д., Пилипенко I. Від "розірваного“ простору до метрополізації і субурбанізації: Херсонська міська агломерація у нових вимірах урбогенезу / Урбаністична Україна: в епіцентрі просторових змін : монографія / за ред. К. Мезенцева, Я. Олійника, Н. Мезенцевої. Київ: Фенікс, 2017, 326-338]

Mandeli, K. (2019). Public space and the challenge of urban transformation in cities of emerging economies: Jeddah case study. Cities, 95, 102409.

Mezentsev, K., Provotar, N., \& Palchuk, M. (2020). Public spaces through the lens of participatory urban planning - the case of Kyiv. Ukrainian Geographical Journal, 2(110), 30-37. [In Ukrainian]. [Мезенцев К. В, Провотар Н. I., Пальчук М. В. Публічні простори через призму партисипативного міського планування - приклад Києва // Український географічний журнал. 2020. Вип. 2 (110). С. 30-37]

Mezentsev, K., Provotar, N., Gnatiuk, O., Melnychuk, A., Denysenko, O. (2019). Ambiguous suburban spaces: trends and peculiarities of everyday practices change. Ekonomichna ta Sotsialna Geografiya, 82, 4-19. [In Ukrainian]. [Мезенцев К., Провотар Н., Гнатюк О., Мельничук А., Денисенко О. Неоднозначні приміські простори: тенденції та особливості зміни повсякденних практик // Економічна та соціальна географія. 2019. Вип. 82. С. 4- 19]

Mezentseva, N. (2017). Introduction: is there a place for smart, green, creative cities in Ukraine? In: Urban Ukraine: in the Epicenter of Spatial Changes. Eds.: K. Mezentsev, Ya. Oliynik, and N. Mezentseva. Kyiv: Fenix, 339-345. [In Ukrainian]. [Мезенцева Н. Вступ: чи $є$ в Україні місце розумним, зеленим, креативним містам? / УрбаністичнаУкраїна: в епіцентрі просторових змін: монографія / за ред. К. Мезенцева, Я. Олійника, Н. Мезенцевої. Київ: Фенікс, 2017, 339-345]

Niemets, L., Husieva, N., Mazurova, A., \& Klyuchko, L. (2017). Industrial Kharkiv: conservation or the path to a smart city? In Urban Ukraine: in the Epicenter of Spatial Changes. Eds.: K. Mezentsev, Ya. Oliynik, and N. Mezentseva. Kyiv: Fenix, 357-377. [In Ukrainian]. [Нємець, Л., Гусєва, Н., Мазурова, А., Ключко, Л. Індустріальний Харків: консервація чи шлях до розумного міста? / Урбаністична Україна: в епіцентрі просторових змін: монографія / за ред. К. Мезенцева, Я. Олійника, Н. Мезенцевої. Київ: Фенікс, 2017, 357-377]

Olchak, M. (2017). Participatory strategic planning in local governments. A Guide for United Territorial Communities. Warsaw: Fundacja Rozwoju Demokracji Lokalnej. [In Ukrainian]. [Ольчак М. Партисипативне стратегічне планування в органах місцевого самоврядування. Посібник для об'єднаних територіальних громад. Варшава: Фонд Розвитку Місцевої Демократії, 2017, 105 с.]

Palacin, V., Nelimarkka, M., Reynolds-Cuéllar, P., \& Becker, C. (2020). The design of pseudoparticipation. Proceedings of the 16th Participatory Design Conference 2020 - Participation(s) Otherwise Volume 2.

Sarzynski, A. (2015). Public participation, civic capacity, and climate change adaptation in cities. Urban Climate, 14(1), 52-67.

Semianovskyi, V. (2018). Participative management: a model for governance of territorial communities. Statistics of Ukraine, 1, 47-51. [In Ukrainian]. [Семяновський В. М. Партисипативне управління як модель управління територіальними громадами // Статистика України. 2018. № 1. С. 47-51.]

Sharifi, A., \& Khavarian-Garmsir, A. R. (2020). The COVID-19 pandemic: Impacts on cities and major lessons for urban planning, design, and management. Science of The Total Environment, 749, 142391.

Shaw, K., \& Butler, T. (2020). Urban regeneration. In: International Encyclopedia of Human Geography (Second Edition), pp. 97-103.

Suptelo, O. (2020). Post-industrial transformations of the old-industrial districts of Kharkiv. Ekonomichna ta Sotsialna Geografiya, 83, 53-62. [In Ukrainian]. [Суптело О. Постіндустріальні трансформації старопромислових районів міста Харкова // Економічна та соціальна географія. 2020. Вип. 83. С. 53-62]

Transforming our world: the 2030 Agenda for Sustainable Development (2015). Resolution adopted by the General Assembly on 25 September 2015, 70/1 [online]. Access mode: http://www.un.org/ga/search/view_doc.asp?symbol=A/ $\mathrm{RES} / 70 / 1 \&$ Lang $=\mathrm{E}$

Trudeau, D. (2013). A typology of New Urbanism neighborhoods. Journal of Urbanism: International Research on Placemaking and Urban Sustainability, 6(2), 113-138.

Urban territories changes of in Ukraine (2013). Eds.: L. G. Rudenko, Kyiv: Referat, 160. [In Russian].

[Изменения городского пространства в Украине / Под ред. Л. Г. Руденко. Киев: Реферат, 2013. 160 с.]

Urban Ukraine: in the Epicenter of Spatial Changes (2017). Eds.: K. Mezentsev, Ya. Oliynik, and N. Mezentseva. Kyiv: Fenix. [In Ukrainian]. [Урбаністична Україна: в епіцентрі просторових змін : монографія / за ред.: К. Мезенцева, Я. Олійника, Н. Мезенцевої. Київ: Вид-во «Фенікс», 2017. 438 с.] 